\title{
The vulnerability of British aquatic insects to climate change
}

\author{
Craig R. Macadam ${ }^{1, *}$, Judy England ${ }^{2}\left(\right.$ ) and Richard Chadd $^{2}$ \\ ${ }^{1}$ Buglife - The Invertebrate Conservation Trust, Unit 4, Beta Centre, Stirling University Innovation Park, Stirling FK9 4NF, UK \\ 2 Environment Agency Horizon House, Deanery Rd, Bristol, BS1 5AH, UK
}

Received: 15 June 2021 / Accepted: 13 January 2022

\begin{abstract}
Freshwater ecosystems are particularly at risk from climate change due to the intrinsic link between the physical properties of the water environment and those species that live there. Mayflies, stoneflies and caddisflies are key indicators of the health of freshwater environments and their biological traits and ecological preferences determine their vulnerability to climate change. Traits and preferences for 289 British species were analysed, with voltinism, length of flight period, altitudinal preference and affinity to headwaters being the main factors causing vulnerability. Sixteen species were deemed to be at risk from climate change. These species are distributed across Great Britain, but particular hotspots of vulnerability are present in upland areas. These areas should be targeted with mitigation measures to reduce the impacts of climate change on populations of aquatic insects.
\end{abstract}

Keywords: Climate / indicators / Ephemeroptera / Plecoptera / Trichoptera

\section{Introduction}

Climate change is recognised as a major driver of change in nature, globally (Diaz et al., 2019; Hannah, 2014). Freshwater habitats and species are particularly at risk, because of profound effects of physical properties of the water environment and resultant effects on ecosystem functioning (Macan, 1963, Brittain, 2008; Darwall et al., 2018). The impacts of climate change on freshwaters are likely to include increased air and water temperatures, and an increased extent and frequency of flooding and droughts (Watts et al., 2015). All these potential changes have been documented to affect invertebrate communities e.g. temperature (Durance and Ormerod, 2007; Taubmann et al., 2011), flooding (Scrimgeour and Winterbourn, 1989; Death, 2008) and drought (Stubbington et al., 2016; Chadd et al., 2017).

The predicted changes to freshwater invertebrates from rising temperatures and flow regime alterations (Domisch et al., 2013) are expected to manifest particularly in montane and submontane regions (Domisch et al., 2011; Monbertrand et al., 2019), as well as in headwaters (Baranov et al., 2020). There may also be other impacts as a result of climate change, such as a decrease in organism size (e.g. Jonsson et al., 2015; Jourdan et al., 2019), changes in the composition of the benthic invertebrate community (e.g. Durance et al., 2009, Woodward et al., 2010; Moss, 2014;), and changes in the distribution of individual species (e.g. Hickling et al., 2005; 2006), including

\footnotetext{
*Corresponding author: craig.macadam@buglife.org.uk
}

upstream shifts in range in montane rivers, or phenological changes (Thackeray et al., 2010; Everall et al., 2015).

The vulnerability of freshwater invertebrates to climate change, particularly increased water temperature, has been investigated by a number of authors who have identified both taxa and areas of increased vulnerability. Comprehensive assessments of vulnerability covering the whole of Europe are available for Trichoptera (Hering et al., 2009), Plecoptera (Tierno de Figueroa et al., 2009), Ephemeroptera, Plecoptera and Trichoptera (EPT) (Conti et al., 2014; Hershkovitz et al., 2015) or identifying vulnerable catchments (Markovic et al., 2017). Sandin et al. (2014) also focussed on EPT in Sweden, finding increased climate change sensitivity in areas with predicted increased temperatures. Bhowmik and Schäfer (2015) identified some relationships between climate change and functional traits of EPT, Diptera and Odonata in Germany, while Monbertrand et al. (2019) found areas of vulnerability to climate warming of EPT in the Swiss Alps. The Europe-wide assessments are based on the 25 ecoregions defined by Illies (1978), however, to understand and target where mitigation measures should be implemented, a more precise analysis is required. Several species have also been discovered in Great Britain since the completion of the European studies (e.g. Baetis atlanticus, Siphlonurus aestivalis, Potamophylax nigricornis and Nemoura lacustris) (Macadam et al., 2018; Macadam and Farr, 2021; Hammett, 2012) and the number of endemic species present is under-reported within these wider scale assessments with Brachyptera putata, Perlodes mortoni, Capnia vidua anglica, Taeniopteryx nebulosa britannica, and Rhyacophila septentrionis all now considered endemic to the British Isles (Macadam, 2015; Valladolid et al., 2021). 
C.R. Macadam et al.: Knowl. Manag. Aquat. Ecosyst. 2022, 423, 3

Table 1. Criteria used to assess potential vulnerability of EPT species to climate change.

\begin{tabular}{|c|c|}
\hline Field & Criteria \\
\hline Stream zonation preference & $\begin{array}{l}\text { Taxa with a preference for the eucrenal, hypocrenal or epirhithral zones classified as a } \\
\text { total score of } 5 \text { or more in these zones according to Schmidt-Kloiber and Hering (2015) }\end{array}$ \\
\hline Altitude preference & $\begin{array}{l}\text { Taxa with a preference for altitudes of } 450 \text { metres and above classified as a total score of } \\
5 \text { or more in the montane zone (for low mountain ecoregions) and above according to } \\
\text { Schmidt-Kloiber and Hering (2015) }\end{array}$ \\
\hline Temperature range preference & Taxa classified as cold stenotherms \\
\hline $\begin{array}{l}\text { Life duration or } \\
\text { Reproductive life cycles per year }\end{array}$ & $\begin{array}{l}\text { Taxa which reproduce every year or every two years classified as univoltine or } \\
\text { semivoltine or }\end{array}$ \\
\hline & Taxa with a life span of more than one year. \\
\hline Duration emergence period & Emergence period of 2 month or less \\
\hline Restricted distribution & Classified as 'Nationally Rare' in Macadam $(2015 ; 2016)$ or Wallace (2016) \\
\hline
\end{tabular}

In Great Britain, climate change is causing widespread changes in the abundance, distribution and ecology of a range of wildlife (e.g. Franco et al., 2006; Morecroft and Speakman, 2015; Watts et al., 2015; Morris, 2018; Hayhow et al., 2019) including invertebrates (e.g. Durance and Ormerod, 2007, 2008; Pearce-Higgins et al., 2017; SEPA, 2019) and the importance of biological traits and environmental conditions when identifying indicator organisms for climate change investigated (Elliott, 1991; Pearce-Higgins et al., 2015). The use of biological traits and ecological preferences to assess vulnerability to climate warming is well established (e.g. Domisch et al., 2011, 2013, Conti et al., 2014; Hershkovitz et al., 2015). Species with specialist traits, such as low dispersal ability or intolerance to warm or highly variable temperatures, are likely to show range contractions or even local extinctions (Brittain, 2008), whereas generalist species are likely to be able to adapt to changing conditions (Townsend and Hildrew, 1994) and those with greater dispersal ability may find alternative locations (Hickling et al., 2005). For aquatic invertebrates, these studies found that biological traits including emergence period, voltinism, oviposition behaviour, functional feeding type, thermal preference, and droughttolerance influenced species abundance with increases in temperature and precipitation. However, there is no comprehensive assessment of the vulnerability to climate change of British EPT species. To address this knowledge gap we considered the potential vulnerability of British EPT species, based on functional ecological traits. We assessed 289 species present in British waters (both running and standing water habitats) using a selection of traits to investigate their vulnerability to climate warming and the geographical distribution of vulnerable species.

\section{Methods}

To identify the vulnerability of EPT species to climate warming in Great Britain we used six traits adapted from those identified by Hering et al. (2009) (Tab. 1).

We obtained the data on the various biological traits and ecological preferences for British EPT from data compiled for European taxa (Buffagni et al., 2009; Graf et al., 2008, 2009; Schmidt-Kloiber and Hering, 2015). For each species, traits were scored using a binary system where a score of 0 was assigned if the species did not satisfy the criteria for vulnerability and a score of 1 if the species satisfied the criteria. We used this absolute approach to ensure that we identified the most vulnerable species. Where trait information was not available the score was treated as 0 (i.e. the criteria was not satisfied). Whilst this had the potential to under-estimate the vulnerability of the species, none of the species with individual missing traits would have been considered vulnerable if the missing criteria had been satisfied. One species (Baetis atlanticus) was not included in the trait database and was therefore not assessed. The Vulnerability Score (VS) for each species was calculated by summing the individual scores of each trait, therefore giving a score between 0 and 6 . The overall potential vulnerability of species to climate change was defined according to the VS with those scoring 6 as most vulnerable, 5 as highly vulnerable, 4 as vulnerable and 3 or less as invulnerable.

We obtained distribution records of Ephemeroptera, Plecoptera and Trichoptera species from the National Riverfly Recording Schemes (www.riverflies.org/Recording Schemes). The bulk of these records are derived from the monitoring work of the statutory environment agencies and represent riverine species, with additional records from a range of freshwater habitats from local biological records centres, non-governmental organisations, museums and from individuals. Each species contained in the dataset was assigned the corresponding vulnerability score (VS). We linked the resultant dataset to Level 10 HydroBasins (Lehner and Grill, 2013) using QGIS. Summary data for the number of most vulnerable and highly vulnerable species, and the maximum VS was calculated for each of the 1676 HydroBasins present in Great Britain. The data ranged from 1970 to 2019. The median date of all records fell in 1997 so we used this year to split the dataset. We classified records from before 01/01/1997 as 'historic' and records from on or after 01/01/1997 as 'modern'. We then compared the historical and modern distribution of species potentially vulnerable to climate change.

\section{Results}

Trait data was available for 289 of the 290 EPT species found in British waters (52 Ephemeroptera; 35 Plecoptera; 202 Trichoptera) (Tab. 2). Trait information for the mayfly 
C.R. Macadam et al.: Knowl. Manag. Aquat. Ecosyst. 2022, 423, 3

Table 2. Summary of trait data - number and percentage of species which satisfy the criteria in Table 1 .

\begin{tabular}{llllllll}
\hline & $N$ & $\begin{array}{l}\text { Headwater } \\
\text { preference }\end{array}$ & $\begin{array}{l}\text { High altitude } \\
\text { preference }\end{array}$ & $\begin{array}{l}\text { Cold temperature } \\
\text { preference }\end{array}$ & Long-lived & $\begin{array}{l}\text { Short flight } \\
\text { period }\end{array}$ & $\begin{array}{l}\text { Restricted } \\
\text { distribution }\end{array}$ \\
\hline Ephemeroptera & 52 & $2(4 \%)$ & $3(6 \%)$ & $2(4 \%)$ & $18(35 \%)$ & $35(67 \%)$ & $8(15 \%)$ \\
Plecoptera & 35 & $19(54 \%)$ & $5(14 \%)$ & $15(43 \%)$ & $21(60 \%)$ & $30(86 \%)$ & $5(14 \%)$ \\
Trichoptera & 202 & $48(24 \%)$ & $9(5 \%)$ & $23(11 \%)$ & $69(34 \%)$ & $84(42 \%)$ & $26(13 \%)$ \\
Total & 289 & $69(24 \%)$ & $17(6 \%)$ & $40(14 \%)$ & $108(37 \%)$ & $149(52 \%)$ & $39(14 \%)$ \\
\hline
\end{tabular}

Baetis atlanticus, a relatively newly identified UK species (Macadam et al., 2018) was not available. Plecoptera dominated the vulnerable species based on all traits apart from restricted distribution. In contrast, Ephemeroptera were poorly represented for most traits, apart from life history characteristics (i.e. voltinism and flight period). In total 16 EPT species were classed as vulnerable (13 spp.) or highly vulnerable (3 spp.), no species were classified as most vulnerable (Tab. 3; Supplementary information: Tab. 1).

585,807 species distribution records were available from the Riverfly Recording Schemes (111,032 Ephemeroptera; 49,670 Plecoptera; and 425,105 Trichoptera). Distribution data was available for 1585 (95\%) HydroBasins (Fig. 1). Potentially vulnerable species (i.e. species with VS of 4 or more) were found in 579 HydroBasins distributed across Great Britain (Fig. 2). The greatest concentration of vulnerable species is in upland areas (Fig. 2) including Snowdonia, the Cairngorms, Peak District, and Lake District, however they also occur in lower numbers in lowland areas such as East Anglia where they are associated with springs and headwaters.

The comparison between the historical and modern distribution of species potentially vulnerable to climate change resulted in $332(21 \%)$ HydroBasins with potentially vulnerable species in the historic period and $330(21 \%)$ HydroBasins with potentially vulnerable species in the modern period. $106(7 \%)$ HydroBasins have records of potentially vulnerable species in both periods indicating that vulnerable species have not yet been extirpated from the Hydrobasin due to climate change (Supplementary information: Figs. 1-4).

\section{Discussion}

Previous studies have provided an overview of climate vulnerability of Ephemeroptera, Plecoptera and Trichoptera (EPT) species across Europe (Tierno de Figueroa et al., 2009; Hering et al., 2009; Conti et al., 2014; Hershkovitz et al., 2015). Whilst these studies have included Great Britain, they have treated it as a single ecoregion as described by Illies (1978). To inform effective conservation action, a finer precision is required. Therefore, this study has identified the species likely to be vulnerable to climate change and the HydroBasins where they occur within Great Britain.

There were 16 EPT species recorded as vulnerable or highly vulnerable within this study. This compares with 157 species identified within a European study of Ephemeroptera with only one identified within Great Britain (Hershkovitz et al., 2015-Appendix A). The Trichoptera recorded as vulnerable were 3, compared to 543 across Europe (Hering et al., 2009) and 2 compared to 43 for Plecoptera (Tierno de Figueroa et al., 2009). This difference likely reflects in part the discovery of new species in Great Britain since the completion of the European studies, and the consideration of previously overlooked endemic species. According to the river typology of Great Britain the vulnerable species identified in this study can be split into three categories:

\subsection{Species that predominately occur in upland areas}

Ameletus inopinatus ( $\mathrm{VS}=4$ ) is recognised as a species likely to be affected by rising temperatures (Taubmann et al., 2011) and, whilst still relatively common in Great Britain, the impact of rising water temperatures on this species is already evident (Kitchen et al., 2010). This species was considered to have a vulnerability score of 2 on a range of $0-6$, indicating a lower vulnerability across Europe (Hershkovitz et al., 2015).

Glossosoma intermedium (VS =5) has always had a very restricted distribution in Great Britain focussed on the Lake District. However, with no new records since 2001 it is feared that this species may already be extinct (Wallace, 2016). Whilst the pesticide Cypermethrin has been suggested as a possible cause of the decline in this species (Wallace, 2011), the effects of climate change may have contributed to its possible extinction in Britain. This species was considered to have a vulnerability score of 4 , indicating a similar vulnerability across Europe (Hershkovitz et al., 2015).

Protonemura montana (VS $=4$ ) has generally been found in Great Britain at altitudes of 550 metres and above (Hynes, 1977). Recent surveys by one of the authors have failed to rediscover this species at many of its historical sites, suggesting that climate change may already be impacting upon this species. It scored 2 on a scale of 1 to 6, indicating a lower vulnerability across Europe (Hershkovitz et al., 2015). Diura bicaudata (VS $=4$ ) is another upland species, generally found in small stony streams and stony lake shores above 300 metres (Hynes, 1977). In contrast with P. montana, this species is still relatively widespread and common in suitable habitats. Similarly, Capnia atra (VS=4) and Capnia vidua anglica $(\mathrm{VS}=5)$ are both principally found in upland areas. C. vidua anglica is found in small streams at high altitude whereas C. atra is typically found in deep lakes of glacial origin, but may also be found in small high altitude streams. Records of both species are declining, despite seemingly suitable habitats 


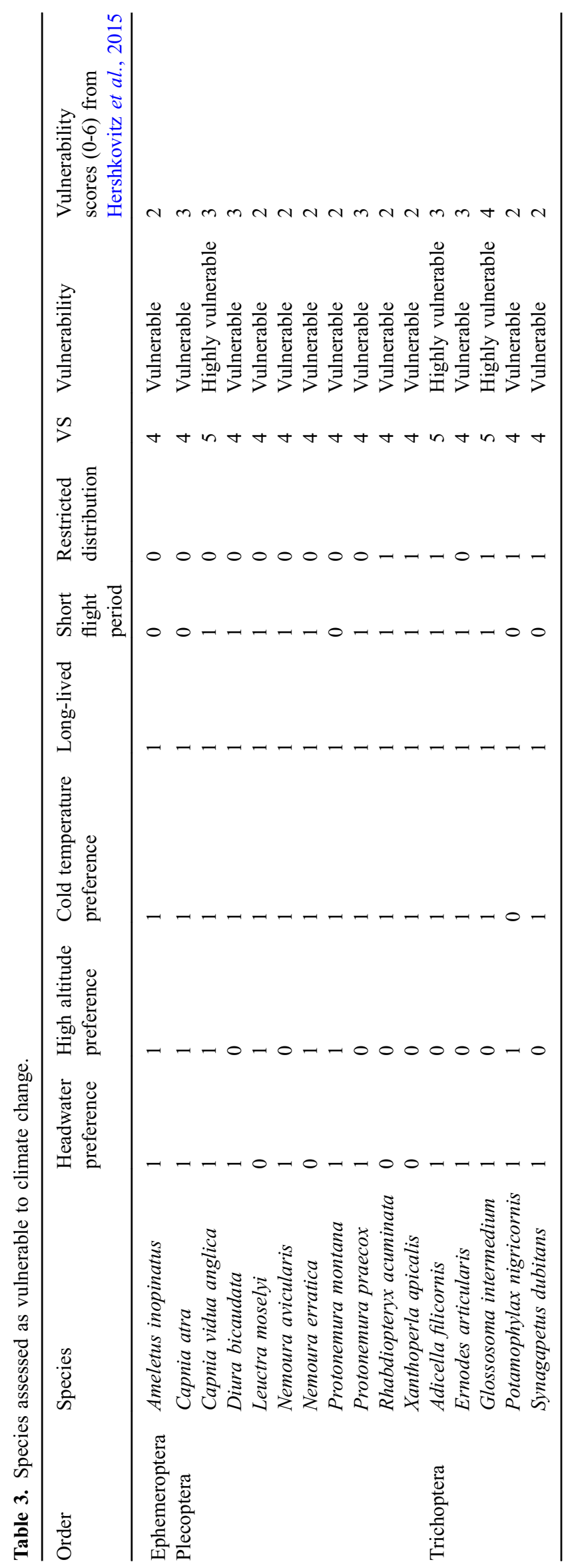

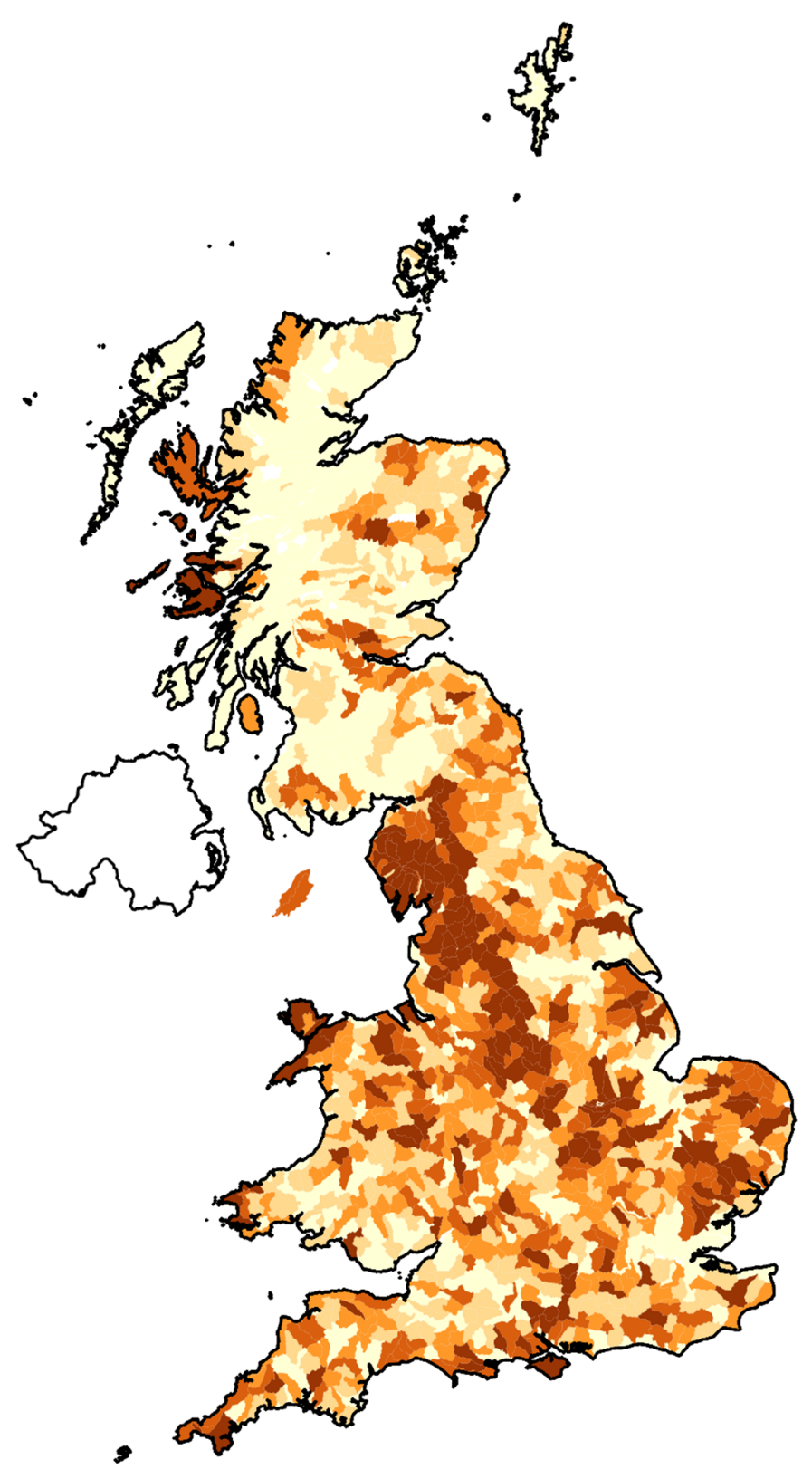

Fig. 1. Distribution of records obtained from the riverfly recording schemes.

being present, possibly reflecting climate change impacts. These three stoneflies were all scored 3 by Hershkovitz et al. (2015) indicating similar or slightly lower vulnerability across Europe.

\subsection{Species that predominately occur in small streams of lowland areas}

The three other potentially vulnerable caddisfly species are all associated with small streams in lowland areas. In the case of Synagapetus dubitans (VS=4) and Ernodes articularis $(\mathrm{VS}=4)$, and at some sites for Adicella filicornis $(\mathrm{VS}=5)$, the streams are travertine depositing waters (Wallace, 2016). At all 

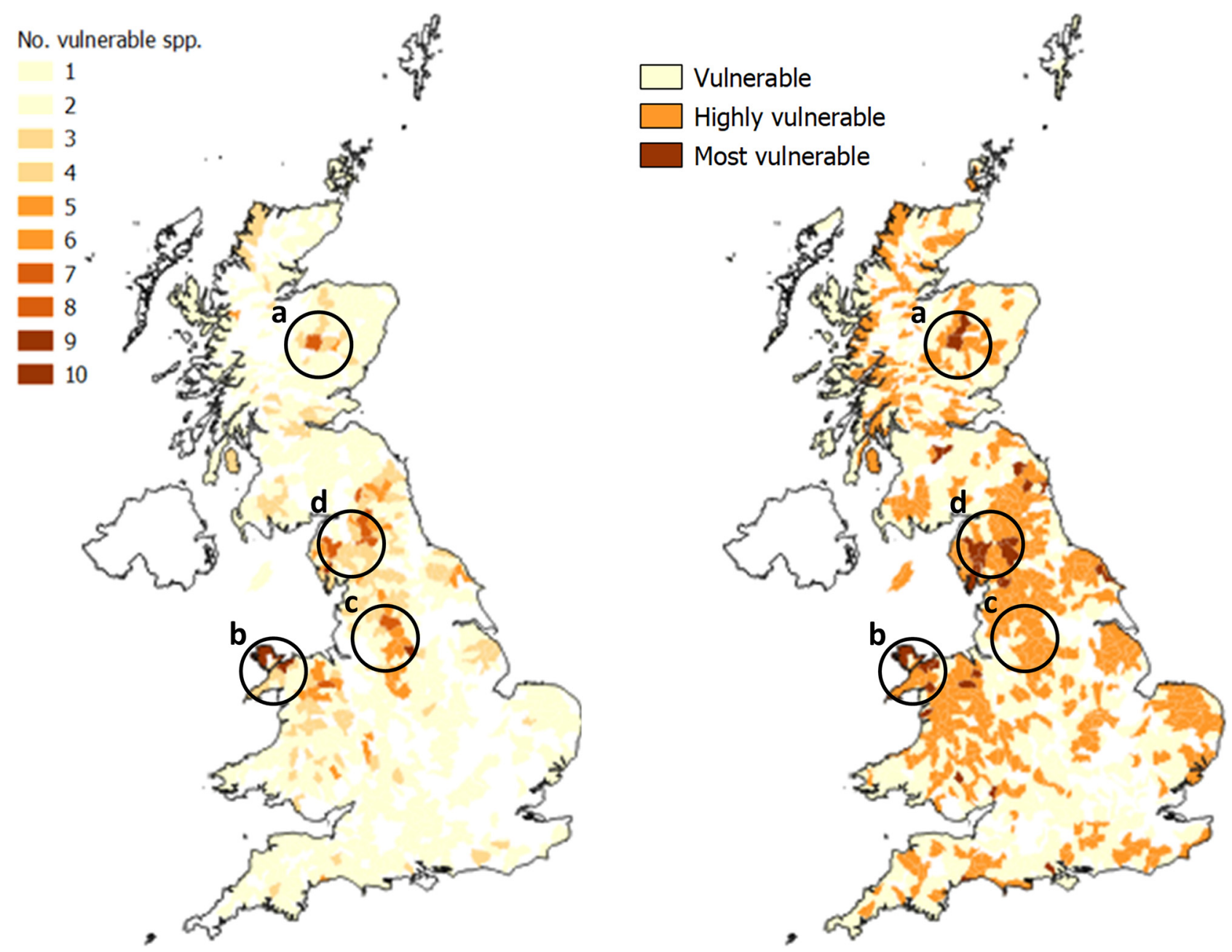

Fig. 2. (Left) Number of potentially vulnerable species (right) Vulnerability in Hydrobasins. Areas circled=a) Cairngorms; b) Snowdonia; c) Peak district; d) Lake District.

sites the species are found close to the spring head of the streams, which may result in a very narrow range of cool groundwater temperatures. In addition, most sites are associated with woodland which further regulates local temperatures through shading (Dohet et al., 2015). Their preference for spring heads means that there is no opportunity for individuals to move further upstream as water temperatures rise, leaving them trapped in a warming environment. These species were all considered less vulnerable across Europe (Hershkovitz et al., 2015).

Rhabdiopteryx acuminata $(\mathrm{VS}=4)$ has a relatively restricted distribution in Wales and England where it occurs in the middle reaches of small, often calcareous, streams (e.g. Kimmins, 1943; Bratton, 1990). Whilst now considered extinct in Great Britain, the stonefly Xanthoperla apicalis $(\mathrm{VS}=4)$, which is found in lowland rivers, is also highlighted as potentially vulnerable. This contrasts with the situation across Europe where they were assessed as having a lower vulnerability to climate change (Hershkovitz et al., 2015).

\subsection{Species found at various altitudes}

Protonemura praecox (VS=4) and Leuctra moselyi $(\mathrm{VS}=4)$ are both widespread and relatively common species. They are both found in small, fast flowing streams from the middle reaches up to high altitudes. Nemoura avicularis $(\mathrm{VS}=4)$ and $N$. erratica $(\mathrm{VS}=4)$ are also both widespread and common species. $N$. avicularis is found in springs and headwaters, as well as in lakes and other standing waters from sea level to high altitudes. N. erratica is predominately found in fast flowing smaller streams at mid to high altitudes. The latter is also a common component of cool water in low altitude spring heads. The caddisfly Potamophylax nigricornis (VS = 4) has recently been discovered in England, where it was found in a small limestone spring. These species were all found 
to have a lower vulnerability to climate change across Europe (Hershkovitz et al., 2015).

Geographically, potentially vulnerable species are concentrated mainly in upland areas ( 450-1300m above sea level), such as the Cairngorms, Lake District, Snowdonia and north Wales, and the Peak District (Fig. 2). Whilst the number of HydroBasins with potentially vulnerable species in the historic and modern periods is almost identical (332 vs. 330), under a third of these HydroBasins (106) contain potentially vulnerable species in both time periods. This suggests that the distribution of the potentially vulnerable species, and therefore the occupied HydroBasins, has changed. A recent focus on monitoring in smaller watercourses and upland areas has resulted in an increase in modern records of species identified as potentially vulnerable in this study. However, there have been decreases in the number of potentially vulnerable species in some areas. For example, in Wales the number of potentially vulnerable species present in HydroBasins is far less for modern records compared with historical records (Fig. 3). This reduction in records may indicate the effects of other pressures such as land use and riparian habitats which are known to be partly important to insect populations in streams (Staponites et al., 2019; Goss et al., 2020) and warrants further investigation. Equally the change may reflect a difference in sampling effort between the two investigation periods within Wales.

\subsection{Application of the results}

The results of this study have the finer precision than the European studies (e.g. Hershkovitz et al., 2015) needed to inform management actions at a national scale. Our findings highlight where HydroBasins are vulnerable to climate change impacts. Knowing where vulnerable species are located or have been recorded in the past can be used to target surveys to track their distribution and population strength and to better understand their ecological requirements and actions needed to conserve them. This understanding will allow land-owners and river managers to identify where measures can be implemented to help these river systems adapt to climate change and where increases in river temperature could be mitigated. In particular planting riparian woodlands, which provide shade to watercourses, is an important measure (Bowler et al., 2012; Broadmeadow et al., 2010; Kristensen et al., 2013). Such planting will need a strategic approach and take time to have an effect, so will need to be put in place at the earliest opportunity to ensure success (Wilby and Johnson, 2020). However, when targeting such actions, it is also important to consider the impact on aquatic invertebrate species composition due to increased coarse organic matter such as dead leaves and other woody debris in the watercourse (Thomas et al., 2016). Species associated with headwaters and springs dominated those considered vulnerable within this study. This highlights the importance of such water courses and the need for their restoration and protection (Riley et al., 2018).

Reducing other pressures, such as over-grazing, pollution, and abstraction, which interact with climate change, and creating more heterogeneity in the landscape in HydroBasins with potentially vulnerable species are also important actions (Clarke, 2009). As water temperature is strongly controlled by climate variability and change but mediated by catchment properties, incorporating an integrated approach is needed for measures to be effectively implemented to increase ecological resilience (Wilby and Johnson, 2020). An improved mechanistic understanding of how climate change may impact on particular species will help target adaptation measures more effectively. This, combined with extending the analysis presented here to different invertebrate groups will help provide the evidence needed to ensure that climate change adaption measures are implemented in a more coherent and effective way.

\section{Supplementary information}

Figure S1: Comparison of historic and modern records of vulnerable species in Wales

Figure S2: Comparison of historic and modern records of vulnerable species in northern England

Figure S3: Comparison of historic and modern records of vulnerable species in England and Wales

Figure S4: Comparison of historic and modern records of vulnerable species in Scotland

Table S1: Trait and preferences for 289 EPT species plus assessment of vulnerability to climate change.

The Supplementary Material is available at https:/www.kmae. org/10.1051/kmae/2022003/olm.

Acknowledgements. This paper is dedicated to the memory of Richard Chadd who sadly passed away before its publication. The authors would like to thank Dr Ian Wallace for access to the Trichoptera Recording Scheme dataset. Similarly, thanks are due to everyone that has contributed records to the Riverfly Recording Schemes over the years. The views expressed in this paper are those of the authors and not the Environment Agency. We also thank Astrid Schmidt-Kloiber and the anonymous reviewer for their comments which have greatly improved our manuscript.

\section{References}

Baranov V, Jourdan J, Pilotto F, Wagner R, Haase P. 2020. Complex and nonlinear climate-driven changes in freshwater insect communities over 42 years. Conserv Biol 34: 1241-1251.

Bhowmik AK, Schäfer RB. 2015. Large scale relationship between aquatic insect traits and climate. PLOS ONE 10: e0130025. https:// doi.org/10.1371/journal.pone.0130025.

Bowler DE, Mant R, Orr H, Hannah DM, Pullin AS. 2012. What are the effects of wooded riparian zones on stream temperature? Environ Evid 1: 3.

Bratton JH. 1990. A review of the scarcer Ephemeroptera and Plecoptera of Great Britain. Nature Conservancy Council, Peterborough, UK. Research \& survey in Nature Conservation no. 29: 1-39.

Brittain JE. 2008. Mayflies, biodiversity and climate change, in International Advances in the Ecology, Zoogeography and Systematics of Mayflies and Stoneflies, edited by F.R. Hauer, J.A. Stanford, R.L. Newell. Berkeley, CA, USA: University of California Press, pp. 1-14.

Broadmeadow SB, Jones JG, Langford TEL, Shaw PJ, Nisbet TR. 2010. The influence of riparian shade on lowland stream water temperatures in southern England and their viability for brown trout. River Res Appl 27: 226-237. 
Buffagni A, Cazzola M, López-Rodríguez MJ, Alba-Tercedor J, Armanini DG. 2009. Distribution and Ecological Preferences of European Freshwater Organisms. Volume 3-Ephemeroptera, edited by A. Schmidt-Kloiber, D. Hering. Pensoft Publishers (Sofia-Moscow). 254pp.

Chadd RP, England JA, Constable D, et al. 2017. An index to track the ecological effects of drought development and recovery on riverine invertebrate communities. Ecol Ind 82: 344-356.

Clarke SJ. 2009. Adapting to climate change: implications for freshwater biodiversity and management in the UK. Freshw Rev 2: 51-64.

Conti L, Schmidt-Kloiber A, Grenouillet G, Graf W. 2014. A traitbased approach to assess the vulnerability of European aquatic insects to climate change. Hydrobiologia 721: 297-315.

Darwall W, Bremerich V, De Wever A, et al. 2018. The Alliance for Freshwater Life: A global call to unite efforts for freshwater biodiversity science and conservation. Aquat Conserv Mar Freshw Ecosyst 28: 1015-1022.

Death R. 2008. The effect of floods on aquatic invertebrate communities. Aquatic insects: Challenges to populations. London: Royal Entomological Society.

Diaz S, Settele J, Brondízio ES, et al.2019. IPBES: Summary for policymakers of the global assessment report on biodiversity and ecosystem services of the Intergovernmental Science-Policy Platform on Biodiversity and Ecosystem Services. IPBES secretariat, Bonn, Germany. 56 pages. https://doi.org/10.5281/zenodo.3553579.

Dohet A, Hlúbiková D, Wetzel CE, et al. 2015. Influence of thermal regime and land use on benthic invertebrate communities inhabiting headwater streams exposed to contrasted shading. Sci Total Environ 505: 1112-1126.

Domisch S, Jähnig SC, Haase P. 2011. Climate-change winners and losers: stream macroinvertebrates of a submontane region in Central Europe. Freshw Biol 56: 2009-2020.

Domisch S, Araújo MB, Bonada N, Pauls SU, Jähnig SC, Haase P. 2013. Modelling distribution in European stream macroinvertebrates under future climates. Glob Change Biol 19: 752-762.

Durance I, Ormerod S. 2007. Climate change effects on upland stream macroinvertebrates over a 25-year period. Glob Change Biol 13: 942-957.

Durance I, Ormerod S. 2008. Evaluating climatic effects on aquatic invertebrates in southern English rivers. Environment Agency Science Report SC070046. https://assets.publishing.service.gov. uk/government/uploads/system/uploads/attachment_data/file/ 291640/scho0908boqy-e-e.pdf [accessed 04/01/2021].

Durance I, Vaughan IP, Ormerod S. 2009. Evaluating climatic effects on aquatic invertebrates, Phase II: review, comparisons between regions and methodological considerations. Environment Agency Science Report: SC070047/R1. https://assets.publishing.service. gov.uk/government/uploads/system/uploads/attachment_data/file/ 291642/scho1209brjt-e-e.pdf [accessed 04/01/2021].

Elliott JM. 1991. Aquatic insects as target organisms for the study of effects of projected climate change in the British Isles. Freshw Forum 1: 196-203.

Everall NC, Johnson MF, Wilby RL, Bennett CJ. 2015. Detecting phenology change in the mayfly Ephemera danica: responses to spatial and temporal water temperature variations. Ecol Entomol 40: 95-105.

Franco AMA, Hill JK, Kitschke C, et al. 2006. Impacts of climate warming and habitat loss on extinctions at species' low-latitude range boundaries. Glob Change Biol 12: 1545-1553.

Goss CW, Sullivan SMP, Goebel PC. 2020. Effects of land-cover transitions on emerging aquatic insects and environmental characteristics of headwater streams in an agricultural catchment. River Res Appl 36: 1097-1108.
Graf W, Lorenz AW, Tierno de Figueroa JM, Lücke S, López-Rodríguez MJ, Davies C. 2009. Distribution and Ecological Preferences of European Freshwater Organisms. Volume 2-Plecopter, edited by A. Schmidt-Kloiber, D. Hering. SofiaMoscow: Pensoft Publishers, 262pp.

GrafW, Murphy J, Dahl J, Zamora-Muñoz C, López-Rodríguez MJ. 2008. Distribution and Ecological Preferences of European Freshwater Organisms. Volume 1-Trichoptera, edited by A. Schmidt-Kloiber, D. Hering. Sofia-Moscow: Pensoft Publishers, 388pp.

Hammett MJ. 2012. Nemoura lacustris Pictet, 1865 (Plecoptera: Nemouridae) - an addition to the British list. Entomolog Monthly Mag 148: 43-45.

Hannah L. 2014. Climate Change Biology 2nd ed. New York, NY: Academic Press.

Hayhow DB, Eaton MA, Stanbury AJ, et al. 2019. State of Nature 2019. State of Nature Partnership, 107pp. https://nbn.org.uk/ stateofnature2019/reports/ [accessed 08/01/2022].

Hering D, Schmidt-Kloiber A, Murphy J, et al. 2009. Potential impact of climate change on aquatic insects: a sensitivity analysis for European caddisflies (Trichoptera) based on distribution patterns and ecological preferences. Aquat Sci 71: 3-14.

Hershkovitz Y, Dahm V, Lorenz AW, Hering D. 2015. A multi-trait approach for the identification and protection of European freshwater species that are potentially vulnerable to the impacts of climate change. Ecol Indic 50: 150-160.

Hickling R, Roy DB, Hill JK, Thomas CD. 2005. A northward shift of range margins in British Odonata. Glob Change Biol 11: 502-506.

Hickling R, Roy DB, Hill JK, Fox R, Thomas CD. 2006. The distributions of a wide range of taxonomic groups are expanding polewards. Glob Change Biol 12: 450-455.

Hynes HBN. 1977. A key to the adults and nymphs of the British stoneflies (Plecoptera). Freshwater Biological Association Scientific Publication 17.

Illies J. (ed.) 1978. Limnofauna Europaea. A Checklist of the Animals Inhabiting European Inland Waters, with an Account of their Distribution and Ecology. 2nd ed. Stuttgart: Gustav Fischer Verlag, 552pp.

Jonsson M, Hedström P, Stenroth K, et al. 2015. Climate change modifies the size structure of assemblages of emerging aquatic insects. Freshw Biol 60: 78-88.

Jourdan J, Baranov V, Wagner R, Plath M, Haase P. 2019. Elevated temperatures translate into reduced dispersal abilities in a natural population of an aquatic insect. J Anim Ecol 88: 1498-1509.

Kitchen L, Macadam CR, Yeomans WE. 2010. Is the Upland Summer Mayfly (Ameletus Inopinatus Eaton 1887) in Hot Water? Windermere, UK: Freshwater Biological Association.

Kimmins DE. 1943. Rhabdiopteryx anglica, a new British species of Plecoptera. Proc Roy Entomolog Soc London Ser B 12: 42-44.

Kristensen PB, Kristensen EA, Riis T, et al. 2013. Riparian forest as a management tool for moderating future thermal conditions of lowland temperate streams. Hydrol Earth Syst Sci Discuss 10: 6081-6106.

Lehner B, Grill G. 2013. Global river hydrography and network routing: baseline data and new approaches to study the world's large river systems. Hydrol Process 27: 2171-2186. Data is available at www.hydrosheds.org.

Macadam CR. 2015. A review of the stoneflies (Plecoptera) of Great Britain. Species Status No.20. Natural England Commissioned Report NECR174. pp 41.

Macadam CR. 2016. A Review of the Mayflies (Ephemeroptera) of Great Britain. Species Status No. 28. Natural England Commissioned Report, NECR193. pp 49. 
Macadam CR, Chadd RP, Pickwell A, Doe J. 2018. A new British mayfly: Baetis atlanticus (Soldán \& Godunko, 2006) (Ephemeroptera: Baetidae). Entomologist's Monthly Mag 154: 263-265.

Macadam CR, Farr A. 2021. A new British mayfly: Siphlonurus aestivalis (Eaton, 1903) (Ephemeroptera: Siphlonuridae). Entomolog Monthly Mag 157: 1-7.

Macan TT. 1963. Freshwater Ecology. London, Longmans, cited in Chadd, R and Eversham B. (2010) Chapter 31 (Other Invertebrates) in Silent Summer, edited by N. Maclean. Cambridge University Press.

Markovic D, Carrizo SF, Kärcher O, Walz A, David JNW. 2017. Vulnerability of European freshwater catchments to climate change. Glob Change Biol 23: 3567-3580.

Monbertrand A-LB, Timoner P, Rahman K, et al. 2019. Assessing the vulnerability of aquatic macroinvertebrates to climate warming in a mountainous watershed: supplementing presence-only data with species traits. Water 11: 636.

Morecroft MD, Speakman L. 2015. Biodiversity Climate Change Impacts Summary Report. Living With Environmental Change. ISBN 978-0-9928679-6-6. https://nerc.ukri.org/research/partner ships/ride/lwec/report-cards/biodiversity/ [accessed 18/03/2020].

Morris T. 2018. Scotland's Nature on Red Alert. Scottish Environment Link/WWF Scotland, Perth, 27pp.

Moss B. 2014. Fresh waters, climate change and UK nature conservation. Freshw Rev 7: 25-75.

Pearce-Higgins JW, Brewer MJ, Elston DA, et al. 2015. BICCO-Net II: Final report to the Biological Impacts of Climate Change Observation Network. (BICCO-Net) Steering Group. pp. 69. http:// nora.nerc.ac.uk/id/eprint/512699/1/N512699CR.pdf [accessed 18/ 03/2020].

Pearce-Higgins JW, Beale CM, Oliver TH, et al. 2017. A nationalscale assessment of climate change impacts on species: Assessing the balance of risks and opportunities for multiple taxa. Biol Conserv 213: 124-134. .

Riley WD, Potter ECE, Biggs J, et al. 2018. Small Water Bodies in Great Britain and Ireland: ecosystem function, human-generated degradation, options for restorative action. Sci Total Environ 645: $1598-1616$

Sandin L, Schmidt-Kloiber A, Svenning J-C., Jeppesen E, Friberg N. 2014. A trait-based approach to assess climate change sensitivity of freshwater invertebrates across Swedish ecoregions. Curr Zool 60: 221-232.

Schmidt-Kloiber A, Hering D. 2015. www.freshwaterecology.info an online tool that unifies, standardises and codifies more than 20,000 European freshwater organisms and their ecological preferences. Ecol Ind 53: 271-282.

Scrimgeour GJ, Winterbourn MJ. 1989. Effects of floods on epilithon and benthic macroinvertebrate populations in an unstable New Zealand river. Hydrobiologia 171: 33-44.

SEPA. 2019. The impact of climate change on freshwater invertebrates. Scottish Environment Protection Agency. Stirling,
Scotland. https://www.sepa.org.uk/media/219482/climate chan ge_story_invertebrates.pdf. [Accessed 4 January 2021].

Staponites LR, Barták V, Bílý M, Simon OP. 2019. Performance of landscape composition metrics for predicting water quality in headwater catchments. Sci Rep 9: 14405.

Stubbington R, Gunn J, Little S, Worrall TP, Wood PJ. 2016. Macroinvertebrate seedbank composition in relation to antecedent duration of drying and multiple wet-dry cycles in a temporary stream. Freshw Biol 61: 1293-1307.

Taubmann J, Theissinger K, Feldheim KA, et al. 2011. Modelling range shifts and assessing genetic diversity distribution of the montane aquatic mayfly Ameletus inopinatus in Europe under climate change scenarios. Conserv Genet 12: 503-515.

Thackeray SJ, Sparks TH, Frederiksen M, et al. 2010. Trophic level asynchrony in rates of phenological change for marine, freshwater and terrestrial environments. Glob Change Biol 16: 3304-3313.

Thomas SM, Griffiths SW, Ormerod SJ. 2016. Beyond cool: adapting upland streams for climate change using riparian woodlands. Glob Change Biol 22: 310-324.

Tierno de Figueroa JM, López-Rodríguez MJ, Lorenz A, Graf W, Schmidt-Kloiber A. 2009. Vulnerable taxa of European Plecoptera (Insecta) in the context of climate change. Biod Conserv 19: 12691277.

Townsend CR, Hildrew AG. 1994. Species traits in relation to a habitat templet for river systems. Freshw Biol 31: 265-275.

Valladolid M, Arauzo M, Chertoprud MV, et al. 2021. The Rhyacophila fasciata Group in Europe: Rhyacophila fasciata Hagen 1859 and formerly synonymized species (Trichoptera: Rhyacophilidae), with new description of Rhyacophila fasciata and Rhyacophila septentrionis McLachlan 1865 (stat. prom.). Zootaxa 4975: 1-57.

Wallace I. 2011. Species dossier: Glossosoma intermedium. Report to Buglife - The Invertebrate Trust, Peterborough, 13pp. https://cdn. buglife.org.uk/2019/07/Glossosoma-intermedium-species-dossier. pdf [accessed 22nd January 2021].

Wallace I. 2016. A review of the status of the caddis flies (Trichoptera) of Great Britain - Species Status No.27. Natural England Commissioned Report NECR191. pp 127.

Watts G, Battarbee RW, Bloomfield JP, et al. 2015. Climate change and water in the UK - past changes and future prospects. Prog Phys Geogr 39: 6-28.

Wilby RL, Johnson MF. 2020. Climate variability and implications for keeping rivers cool in England. Clim Risk Manag 30: 100259.

Woodward G, Perkins DM, Brown LE. 2010. Climate change and freshwater ecosystems: impacts across multiple levels of organization. Philos Trans $R$ Soc Lond B Biol Sci 365: 2093-2106.

Cite this article as: Macadam CR, England J, Chadd R. 2022. The vulnerability of British aquatic insects to climate change. Knowl. Manag. Aquat. Ecosyst., 423, 3. 